\title{
Pelatihan Membuat Buku Penghubung Di PAUD Wejang Asih
}

\author{
Felisitas Ndoet ${ }^{1}$, Petrus Redy Partus Jaya ${ }^{2}$, dan Beata Palmin ${ }^{3}$ \\ 1,2,3 Program Studi Pendidikan Guru PAUD, FKIP UNIKA Santu Paulus Ruteng \\ e-mail corresponden: icananoarta@gmail.com
}

\begin{abstract}
Abstrak. Kegiatan pengabdian kepada masyarakat ini dilaksanakan untuk mengoptimalkan keterlibatan orang tua dalam menstimulasi aspek-aspek perkembangan anak di rumah. Kegiatan pengabdian kepada masyarakat ini dilaksanakan dengan metode brain storming bersama orang tua dan guru serta pendampingan pembuatan buku penghubung bersama guru. Adapun hasil kegiatan pengabdian kepada masyarakat ini berupa buku penghubung PAUD Wejang Asih Mano dan keikutsertaan orang tua dalam menstimulasi aspek-aspek perkembangan anak di rumah. Hasil kegiatan pengabdian kepada masyarakat ini dapat menjadi acuan guru dalam mengamati tindak lanjut stimulasi yang sudah diberikan selama anak berada di satuan PAUD sehingga orang tua tidak lagi menganggap hanya guru di satuan PAUD saja yang bertanggung jawab untuk menstimulasi anak-anak mereka. Kegiatan pengabdian masyarakat ini diharapkan mampu menyadarkan orang tua akan pentingnya kesinambungan antara peran guru dan orang tua dalam mengoptimalkan aspek-aspek perkembangan pada anak agar anak lebih siap saat memasuki sekolah dasar.
\end{abstract}

Kata Kunci : Buku Penghubung Orang Tua, PAUD, Aspek Perkembangan

\begin{abstract}
Community service activities are carried out to meet the demands of teachers in PAUD Wejang Asih Mano who have difficulty optimizing parental involvement instimulating aspects of child development at home. Community service activities are carried out with brain storming method with parents and teachers and mentoring making a contact book with the teacher. As for the results of community service activities in the form of a liaison book Wejang Asih Mano and the participation of parents in stimulating aspects of child development at home. The results of community service activities can become a teacher's reference in observing the stimulation follow-up given to the child while in the PAUD unit so that parents no longer assume that only teachers in the Early Childhood Education unit are responsible for stimulating their children. Community service activities are expected to be able to make parents aware of the importance of continuity between the role of teachers and parents in optimizing aspects of development in children so that children are better prepared when entering elementary school.
\end{abstract}

Keyword : Early Childhood Education Liaison Book, parents, children's development.

\section{PENDAHULUAN}

Berdasarkan hasil diskusi bersama para guru (3 orang) sebelum melaksanakan kegiatan PkM pada tanggal 17 dan 24 Januari 2020, tim PkM memperoleh informasi bahwa para guru mengalami dilema dalam menghadapi tuntutan orang tua agar anak memiliki kemampuan menulis, membaca, dan berhitung saat memperoleh layanan pendidikan di PAUD Wejang Asih sementara aktivitas membaca, menulis, dan berhitung dalam kurikulum anak usia dini hanya diberikan sebagai pengenalan awal mengenai 
angka, huruf, serta mengoptimalkan perkembangan motorik halus anak agar dapat menulis. Aktivitas pengenalan tersebut juga dilaksanakan melalui aktivitas bermain tanpa ada paksaan yang menyebabkan anak merasa terbebani. Menurut Bredecamp dan Copple dalam Masitoh [1], pada dasarnya pembelajaran anak usia dini mengutamakan bermain melalui belajar dan belajar melalui bermain yang bertujuan mengoptimalkan perkembangan dan pertumbuhan anak. Menurut Hurlock (1993), bermain adalah setiap kegiatan yang dilakukan untuk kesenangan yang ditimbulkan tanpa pertimbangan hasil akhir. Melalui bermain anak akan memiliki berbagai manfaat bagi perkembangan, aspek ini saling menunjang satu sama lain dan tidak dapat dipisahkan. Apabila satu aspek tidak diberikan kesempatan untuk berkembang, maka akan terjadi ketimpangan karena bermain adalah aktivitas yang menyenangkan dan merupakan kebutuhan yang sudah melekat dalam diri anak[2]. Selain itu, guru PAUD Wejang Asih tidak memiliki sarana untuk mengikutsertakan orang tua dalam proses memberikan rangsangan pendidikan berupa stimulasi aspek-aspek perkembangan anak di rumah. Salah satu contoh sarana yang dapat digunakan untuk melibatkan orang tua dalam pembelajaran di rumah adalah buku kemajuan belajar seperti yang diterapkan oleh guru dan orang tua di TK Masyithoh 1 Purworejo yang beirisi tugas berkesinambungan untuk membahas topik yang sudah dipelajari di sekolah maupun tugas baru melalui pendampingan oleh orang tua/wali saat anak di rumah [3]. Berdasarkan hasil pengabdian Kristiana menyimpulkan bahwa perlunya kerjasama dengan pihak orang tua dengan melakukan komunikasi efektif berkaitan dengan kegiatan pembelajaran yang dilakukan selama pembelajaran dari rumah karena pelaksana kegiatan adalah orang tua. Berikan penjelasan mengenai pentingnya memberikan stimulasi sejak dini dan melakukan laporan kegiatan anak kepada guru melalui artikel-artikel ataupun melalui komunikasi langsung. Kegiatan dapat berupa perencanaan yang telah dirancang dari lembaga ataupun kegiatan yang dilakukan bersama orang tua di rumah. Kegiatan yang diberikan lebih kepada pengembangan keterampilan hidup dan karakter anak[4]. Oleh karena itu, ketersediaan sarana sebagai penghubung antara guru dan orang tua untuk meningkatkan partisipasi orang tua dalam menstimulasi anak di rumah sangat penting.

Berdasarkan uraian di atas, maka pihak satuan PAUD perlu memiliki sebuah panduan untuk memudahkan orang tua memberikan stimulasi aspek perkembangan anak di rumah yang dapat dipantau oleh guru dan orang tua. Buku panduan ini diharapkan dapat membantu orang tua menyisihkan waktu setelah bekerja saat berada di rumah untuk menstimulasi perkembangan anak karena kenyataan yang terjadi menunjukkan bahwa orang tua lebih mempercayakan guru di sekolah untuk menstimulasi perkembangan anak karena orang tua sibuk bekerja [5]. Panduan tersebut dapat dibuat dalam bentuk sebuah buku penghubung. Adapun buku penghubung tersebut berisi informasi secara umum berkaitan dengan hal-hal yang perlu diperhatikan orang tua pada saat menyiapkan anak sebelum dan setelah anak selesai mengikuti aktivitas belajar di satuan PAUD serta hal-hal khusus berupa informasi berkaitan dengan aktivitas-aktivitas anak di satuan PAUD yang diisi oleh guru agar orang tua mengetahui apa saja yang sudah dilakukan anak selama di bawah bimbingan para guru disertai informasi tentang apa saja yang belum bisa dilakukan anak dan perlu 
mendapat stimulasi lanjutan oleh orang tua di rumah. Buku penghubung tersebut wajib diisi setiap hari oleh guru dan orang tuasehingga pada saat anak datang belajar di satuan PAUD orang tua memasukkan buku penghubung yang sudah diisi dengan informasi mengenai stimulasi yang sudah diberikan oleh orang tua di rumah dan sejauh mana perkembangan anak setelah distimulasi ke dalam tas sekolah anak. Buku penghubung yang telah diisi oleh orang tua kemudian akan dibaca oleh guru lalu diisi kembali oleh guru untuk aktivitas pada hari tersebut kemudian dikembalikan kepada anak untuk dibawa pulang ke rumah dan diserahkan kepada orang tua. Pelibatan orang tua dalam menstimulasi perkembangan anak di rumah melalui panduan dalam buku penghubung ini diharapkan dapat memberikan manfaat yang sangat besar bagi perkembangan anak. Selain bermanfaat bagi perkembangan anak, keterlibatan orang tua dalam pendidikan anak juga bermanfaat untuk menjadikan orang tua lebih cepat tanggap terhadap kebutuhan sosial, emosional, dan perkembangan anak, orang tua lebih memahami perkembangan anak, orang tua lebih dekat dengan anak, orang tua menjadi aktif dan bertanggungjawab terhadap pertumbuhan dan perkembangan anak [6]. Berdasarkan hasil penelitian Cintya menyimpulkan bahwa Keterlibatan orang tua dalam pendidikan anak usia dini perlu sinergi dengan ragam upaya program maupun kegiatan yang disesuaikan dengan analisis kendala-kendala dari pihak orang tua meliputi faktor status sosial, faktor bentuk keluarga, faktor tahap perkembangan keluarga, dan faktor model peran. Selain itu, guru memiliki peran sinergi karena sebagai komunikator pihak sekolah dan anak didik dalam menyampaikan informasi-informasi dan pendidik dalam pengajaran[3].

Melalui kegiatan PkM ini, tim PkM bersama guru PAUD Wejang Asih kemudian merancang sebuah kegiatan yang dapat dijadikan sebagai wadah untuk menyamakan pemahaman tentang keterlibatan orang tua dalam menstimulasi aspek-aspek perkembangan anak di rumah. Selain itu juga kegiatan PkM ini akan menghasilkan sebuah buku penghubung yang menjadi sarana informasi serta panduan bagi orang tua dalam memberikan stimulasi kepada anak di rumah.

\section{METODE}

PAUD Wejang Asih Mano merupakan sebuah lembaga PAUD yang berada di bawah Yayasan Maria Bintang Samudera. PAUD Wejang Asih Mano membuka 3 kelas untuk layanan pendidikan yakni kelas A untuk usia 4-5 tahun dengan jumlah siswa 13 orang, sedangkan 2 kelas lainnya merupakan kelas untuk layanan usia 5-6 tahun yakni kelas B1 dengan jumlah siswa 11 orang dan kelas B2 dengan jumlah siswa 12 orang. Tenaga pendidik terdiri dari 3 orang guru yang menangani masing-masing kelas, serta seorang kepala sekolah. Aktivitas belajar di PAUD Wejang Asih dimulai pukul 08.00 hingga pukul 10.30 setiap hari Senin sampai Sabtu. Hal tersebut menunjukkan bahwa anak-anak berada bersama guru di satuan PAUD dalam 1 hari hanya 2 jam 30 menit, waktu selebihnya lebih banyak dihabiskan anak di rumah bersama orang tua. Oleh karena itu, orang tua perlu terlibat aktif dalam menstimulasi anak di rumah agar anak dapat berkembang dengan lebih optimal. Orang tua perlu diberikan pengetahuan, 
keterampilan, dan pemahaman tentang karakteritik anak agar dapat memberikan stimulasi kepada anak selama anak berada di rumah.

Metode yang digunakan dalam penerapan kegiatan pengabdian kepada masyarakat ini adalah brain storming dan pendampingan yang terdiri dari tahap persiapan, pelaksanaan, dan evaluasi. Pada tahap persiapan, tim PkM (Pengabdian kepada Masyarakat) mengadakan brain storming bersama guru-guru dan orang tua di PAUD Wejang Asih Mano selama satu hari yaitu pada tanggal 08 Januari 2020. Melalui metode brain storming, tim PkM membagikan informasi tentang bentuk-bentuk keterlibatan orang tua dalam menstimulasi aspek-aspek perkembangan pada anak. Para guru dan orang tua secara bergantian menyampaikan hal-hal yang sudah dilakukan dalam menstimulasi aspek-aspek perkembangan anak serta kendala-kendala yang dihadapi. Pada tahap pelaksanaan, guru bersama tim pendamping embuat rancangan buku penghubung sesuai dengan data masukkan hasil brain storming. Pada tahap evaluasi, guru-guru dan tim pendampng mengevaluasi kembali rancangan buku penghubung sebelum digunakan.

\section{HASIL DAN PEMBAHASAN}

Kegiatan brain storming dilaksanakan pada tanggal 08 Januari 2020 bertempat di aula satuan PAUD Wejang Asih Mano. Kegiatan ini dihadiri oleh semua guru dan orang tua siswa PAUD Wejang Asih Mano. Kegiatan PkM yang sudah dilaksanakan di PAUD Wejang Asih Mano melalui brain storming bersama orang tua dan guru berkaitan dengan keterlibatan orang tua dalam menstimulasi perkembangan anak di rumah. Berdasarkan hasil brain storming, ditemukan bahwa orang tua kurang memiliki kesabaran dalam menghadapi anak di rumah, orang tua memiliki kesibukan masing-masing sehingga anak dibiarkan bermain atau belajar sendiri, orang tua kurang memiliki pengetahuan tentang karakteristik perkembangan anak, orang tua mengharapkan guru untuk melatih anak membaca, menulis, dan berhitung., orang tua menganggap hanya guru yang memiliki tanggung jawab untuk menstimulasi aspek perkembangan anak, guru mengharapkan agar orang tua terlibat dalam menstimulasi aspek perkembangan anak di rumah sedangkan orang tua tidak memiliki panduan dalam memberikan stimulasi kepada anak di rumah. Menurut Lestari dalam keterlibatan orangtua, terdapat faktor pendukung dan penghambat terlaksananya program parenting. Faktor pendukung pelaksanaan program parenting antara lain hubungan yang baik antara nara sumber dengan orang tua, kompetensi nara sumber, semangat peserta yang tinggi, dan materi yang sesuai kebutuhan. Sedangkan faktor penghambat pelaksanaan program parenting diantaranya tingkat kesadaran orang tua untuk mengikuti program parenting yang masih rendah, kurang tepat waktu, setting ruangannya yang kurang sesuai untuk pembelajaran orang tua[7].

Berdasarkan hasil brain storming tersebut, tim PkM dan guru-guru PAUD Wejang Asih Mano merencanakan kegiatan pendampingan pembuatan buku penghubung melalui metode pendampingan sebagai solusi untuk mengatasi adanya masalah [8] berupa kesenjangan antara keterlibatan orang tua dan guru dalam 
menstimulasi perkembangan anak. Penerapan metode pendampingan diawali dengan tahapan perencanaan. Guru-guru PAUD Wejang Asih bersama tim PkM membuat perencanaan jadwal pendampingan pembuatan buku penghubung berdasarkan hasil brain storming. Guru-guru dan tim PkM membuat jadwal bersama yaitu setiap hari Jumat selama bulan Februari tahun 2020. Pada tahap pelaksanaan, tim PkM bersama guru-guru PAUD Wejang Asih setiap hari Jumat sepanjang bulan Februari tahun 2020 membuat rancangan buku penghubung lalu diselesaikan hingga menjadi sebuah buku penghubung yang siap pakai. Buku penghubung yang sudah selesai didesain kemudian dievaluasi isi dan kebermanfaatannya dan direncanakan untuk mulai digunakan pada tahun ajaran yang baru.

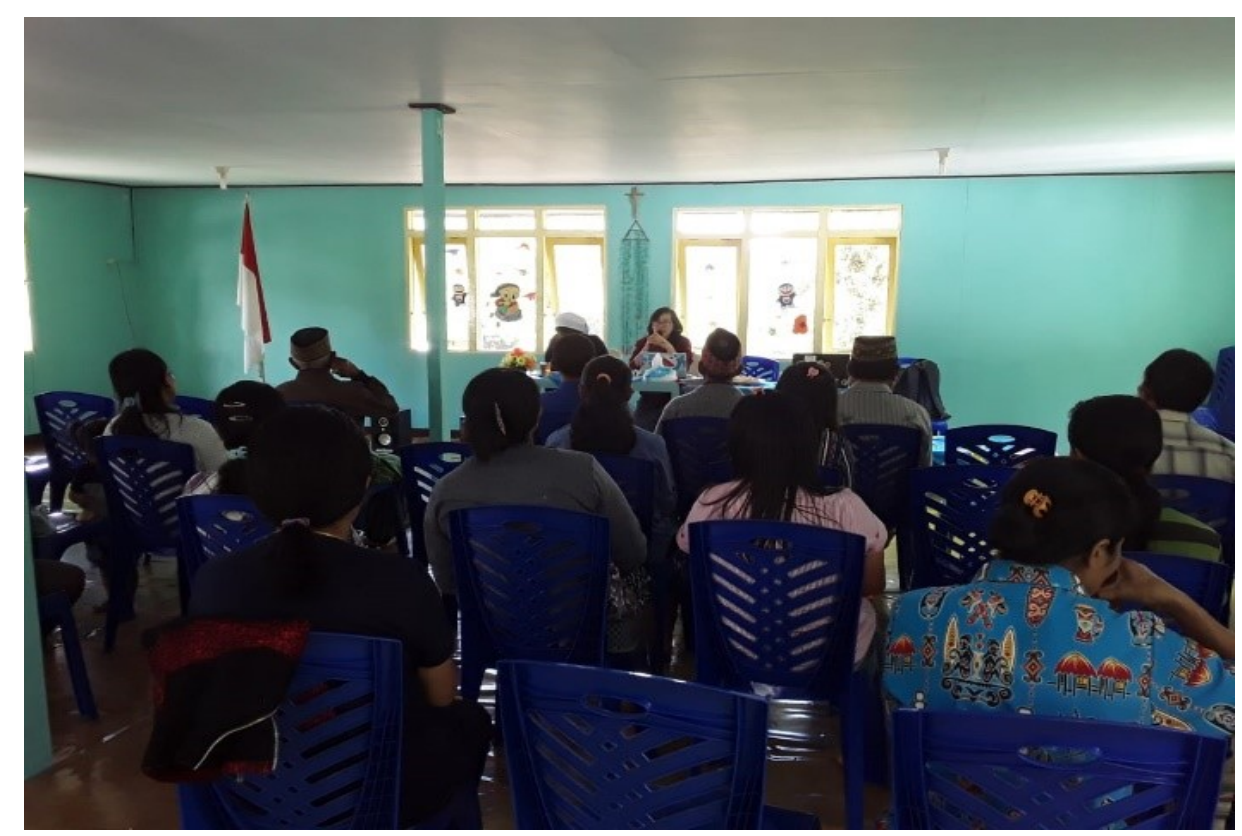

Gambar 1. Kegiatan brain Storming tim PkM bersama guru dan orang tua siswa PAUD Wejang Asih Mano

Berdasarkan hasil brain storming yang telah uraikan di atas, orang tua belum sepenuhnya ikut serta memberikan stimulasi pada perkembangan anak di rumah. Pemberian rangsangan perkembangan kepada anak menjadi tanggung jawab guru sepenuhnya padahal sebagian besar hasil penelitian mengenai keterlibatan orang tua dalam pendidikan anak menunjukkan bahwa keterlibatan orang tua dapat memengaruhi keberhasilan anak dalam bidang pendidikan [9]. Salah satu bentuk keterlibatan orang tua di PAUD adalah pembelajaran di rumah [3]. Orang tua perlu memahami bahwa anak juga berhak memperoleh pendidikan di lingkungan keluarga melalui kegiatan stimulasi perkembangan oleh orang tua di rumah. Menurut Hornby \& Lafaele [10], keinginan orang tua dalam memberikan stimulasi pada anak diprediksi dapat menjadi faktor positif yang memengaruhi proses dan prestasi belajar anak. Sebagian besar waktu yang dihabiskan oleh anak di rumah bersama orang tua dapat dimanfaatkan sebaik-baiknya oleh orang tua untuk meningkatkan kelekatan dengan anak dan membantu anak mengembangkan potensi yang dimilikinya. Guru dan orang tua dapat bekerjasama secara efektif melalui adanya komunikasi berkaitan dengan informasi mengenai 
keadaan anak selama di sekolah maupun di rumah [11]. Agar anak memperoleh stimulasi dari orang tua di rumah maka orang tua juga sangat perlu menyediakan waktu bagi anak.Pihak sekolah juga perlu memberikan pemahaman kepada orang tua akan pentingnya menyediakan waktu bagi anak di rumah. Selain itu, pihak satuan PAUD perlu melibatkan orang tua dengan meningkatkan partisipasi orang tuadi berbagai program di satuan PAUD seperti kunjungan rumah dan melibatkan orang tua dalam penilaian perkembangan anak [12].

Pelibatan orang tua dalam menstimulasi aspek-aspek perkembangan anak di rumah dapat dilakukan melalui aktivitas-aktivitas yang biasa dilakukan anak pada saat bermain, seperti bermain permainan tradisional, kejar-kejaran, bermain pasir/tanah/clay/plastisin, bermain boneka, bermain memasak, menyusun lego, memasang puzzle, bermain bola, menebak warna, mencampur warna, mencorat-coret, menggambar, dan lain-lain. Aktivitas-aktivitas tersebut juga dapat mengalihkan perhatian anak dari kegiatan menonton televisi dan bermain gadget. Hasil penelitian Setianingsih menunjukkan bahwa penggunaan gadget memiliki hubungan dengan resiko gangguan pemusatan perhatian dan hiperaktivitas pada anak usia pra sekolah [13]. Oleh karena itu, anak perlu bersosialisasi dengan teman sebaya dan orang dewasa di sekitarnya agar anak memiliki ativitas lain selain bermain gadget. Peran orang tua dalam mengembangkan aspek sosial emosional pada anak sangat penting. Orang tua berperan sebagai manajer dalam mengatur kesempatan anak untuk melakukan kontak sosial dengan teman sebaya dan orang dewasa [3].

Kegiatan pendampingan pembuatan buku penghubung oleh tim PkM kepada guru-guru PAUD Wejang Asih dilaksanakan setiap hari Jumat selama bulan Februari tahun 2020. Pada tahap perencanaan, para guru dan tim PkM menyusun jadwal kegiatan dan alat serta bahan yang perlu disiapkan untuk digunakan selama kegiatan pendampingan. Tim PkM menyusun rancangan buku penghubung untuk dijadikan contoh saat kegiatan pendampingan pembuatan buku penghubung dilaksanakan. Pada tahap pelaksanaan, para guru bersama tim pkM membuat buku penghubung setiap hari Jumat selama bulan Februari tahun 2020 sampai kemudian menghasilkan sebuah buku penghubung yang siap pakai. Pada tahap evaluasi, tim PkM dan guru-guru PAUD Wejang Asih menganalisis kembali isi buku penghubung lalu merevisi bagian-bagian yang masih belum sesuai. Adapun hasil evaluasi adalah para guru perlu mengadakan sebuah pertemuan yang dikemas dalam kegiatan seminar parenting untuk menginformasikan kepada orang tua cara mengisi buku penghubung dan menstimulasi anak di rumah. Seminar ini akan diadakan bersamaan dengan pertemuan orang tua murid sebelum memasuki tahun ajaran baru di PAUD Wejang Asih. 


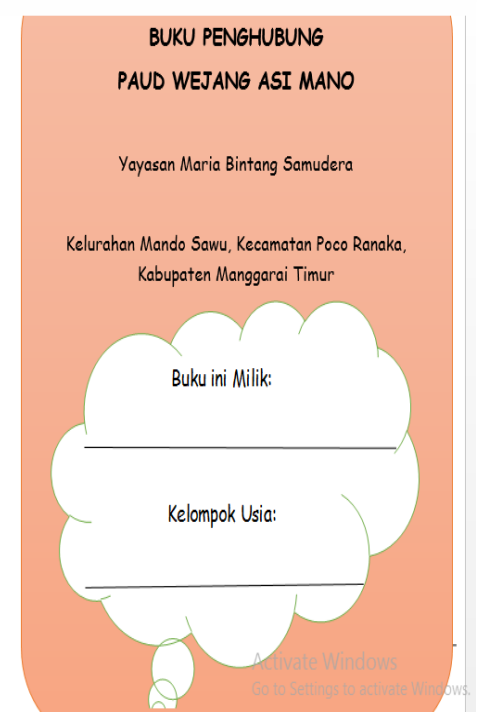

(a)

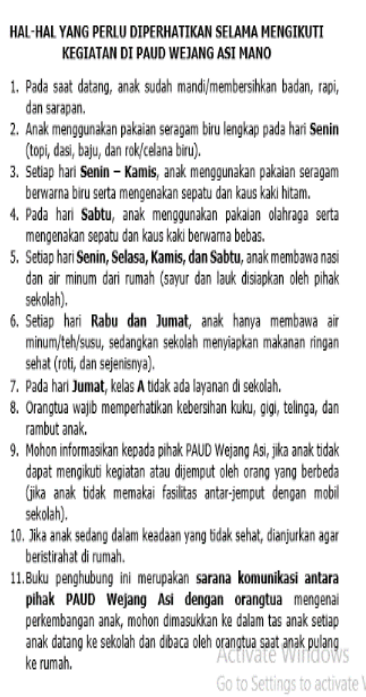

(b)

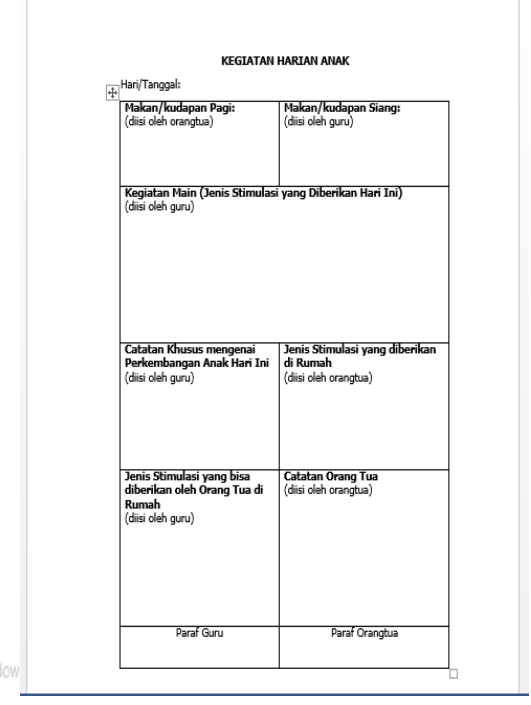

(c)

Gambar 2. Tampilan Buku Penghubung PAUD Wejang Asih (a) Cover, (b) Halaman Informasi, (c) Format Laporan Stimulasi

Buku penghubung sudah dirancang seperti gambar 2 di atas, berisi identitas setiap anak, hal-hal yang perlu diperhatikan selama mengikuti pendidikan di PAUD Wejang Asih, dan kegiatan harian anak. Format kegiatan harian anak berisi waktu; kolom yang memuat informasi tentang kudapan/makan pagi anak yang bisa diisi oleh orang tua jika anak sarapan di rumah, diisi oleh guru jika anak sarapan di sekolah; informasi tentang kudapan siang anak di sekolah yang diisi oleh guru; kegiatan main anak di sekolah (bebas, kelompok, dan outdoor), informasi ini penting agar orang tua mengetahui aktivitas main apa saja yang dilakukan anak di sekolah; kolom catatan khusus dari sekolah diisi oleh guru jika ada peristiwa khusus yang terjadi pada anak berkaitan dengan pertumbuhan maupun perkembangannya maupun aktivitas yang perlu dilakukan bersama anak dan orang tua di rumah sebagai bentuk keterlibatan orang tua dalam menstimulasi anak di rumah; kolom catatan orang tua diisi oleh orang tua dalam bentuk respon positif terhadap catatan khusus yang diberikan guru maupun terlaksana atau tidak terlaksananya stimulasi anak oleh orang tua di rumah serta kendalanya jika ada; dan kolom berikutnya berisi paraf guru dan orangtua. Hasil penelitian Wardani melihat bahwa secara umum kendala- kendala orang tua dalam mendampingi anak belajar di rumah pada masa pandemi Covid- 19 adalah kurangnya pemahaman materi oleh orang tua, kesulitan orang tua dalam menumbuhkan minat belajar anak, tidak memiliki cukup waktu untuk mendampingi anak karena harus bekerja, orang tua tidak sabar dalam mendampingi anak saat belajar dirumah, kesulitan orang tua dalam mengoperasikan gadget, dan kendala terkait jangkauan layanan internet[14]. Pandemi covid 19 memberikan dampak yang besar, termasuk pada pendidikan di lembaga PAUD. Adanya kebijakan dari Pemerintah dengan menerapkan belajar dari rumah sebagai bentuk penanggulangan penyebaran virus corona menyebabkan pola pembelajaran berubah dari belajar di sekolah menjadi belajar dari rumah. Kegiatan belajar dari rumah dapat menjadi titik balik digalakkannya kembali peran keluarga . Keluarga, utamanya orang tua memegang peranan yang sangat penting 
dalm perkembangan karena orang tualah yang paling banyak berinteraksi dengan anak sehingga orang tua dapat memaksimalkan peran utamanya dalam mendidik anak mereka. Orang tua sebagai pendidik utama anak selama belajar dari rumah harus menyediakan waktu, lingkungan belajar yang menyenangkan dan sumber belajar yang beragam agar anak tetap dapat mengembangkan kemampuannya dan mencapai tugastugas perkembangannya. Dengan mendampingi anak di rumah dapat membangun kedekatan hubungan antara orang tua dan anak. Adapun peran penting orang tua dalam mendampingi anak yaitu Anak merasa tidak sendiri, orang tua sebagai pemberi semangat, memfasilitasi kebutuhan anak, tempat berdiskusi dan bertanya, membantu mengenali diri sendiri, melihat dan mengembangkan bakat anak dan menciptakan lingkungan yang kondusif untuk belajar[15].

Secara keseluruhan, buku penghubung ini telah mengefektifkan peran orang tua serta memudahkan guru mengetahui keterlibatan orangtua dalam menstimulasi anak di rumah terutama pada masa pandemi covid-19 saat ini, di mana anak dianjurkan agar belajar di rumah dan belajar daring, sehingga orang tua memiliki kesempatan lebih banyak dalam menstimulasi aspek-aspek perkembangan anak agar tetap berkembang optimal selama masa pandemi ini. Hal ini akan membantu juga guru dalam proses pembelajaran dengan banyaknya kendala dalam pembelajaran online pada masa pandemic covid 19. Berdasarkan hasil penelitian Anhusadar menyimpulkan bahwa masih ada pendidik PAUD yang tidak menjalankan pembelajaran di tengah pandemi covid 19. Masih banyak pendidik PAUD yang belum mahir menggunakan aplikasi pembelajaran online. Metode pembelajaran yang digunakan masih dominan pemberian tugas kepada peserta didik. Banyak pendidik PAUD yang tidak setuju dengan pembelajaran online karena tidak efektif dan tidak semua orang tua yang memiliki leptop atau HP untuk pembelajaran online[16]. Hasil penelitian yang lain dari Wiwin menyimpulkan bahwa Keterlibatan orangtua dalam pendampingan anak selama belajar dari rumah (BDR) di PAUD SKB Cerme Gresik menunjukkan hasil sangat baik. Hasil tersebut didukung dengan adanya kesesuaian hasil pada setiap sub variabel yaitu pada sub variabel peran orangtua dan pendampingan belajar anak. Pendampingan dilakukan dengan cara membantu mengerjakan tugas anak, sebagai tempat belajar anak, menerangkan dan memberikan penjelasan mengenai materi yang dipelajari, memberikan respon yang baik terhadap pembelajaran dari sekolah. Pendampingan diharapkan dapat membentuk karakter anak yang mampu mengerjakan tugas yang telah diperintahkan dari sekolah, mampu mempraktikkan pembelajaran di rumah, dan tanggap dalam menciptakan karya sebagai implementasi pembelajaran[17].

\section{KESIMPULAN}

Berdasarkan hasil kegiatan PkM yang telah dideskripsikan di atas, maka dapat disimpulkan bahwa satuan PAUD perlu melibatkan orang tua dalam menstimulasi perkembangan anak agar berkembang optimal, satuan PAUD perlu memiliki sarana untuk menjalin komunikasi dengan orang tua dalam memantau perkembangan anak, orang tua dan guru bersama-sama menstimulasi perkembangan anak, bukan hanya 
menyerahkan tanggung jawab kepada guru PAUD, orang tua perlu menghabiskan waktu lebih banyak bersama anak di rumah melalui aktivitas bermain yang dilakukan bersama anak, satuan PAUD perlu menyusun program untuk melibatkan orang tua dalam kegiatan di satuan PAUD. Melalui kegiatan pendampingan ini, diharapkan buku penghubung yang dihasilkan dapat benar-benar mengoptimalkan keterlibatan orang tua dalam menstimulasi perkembangan anak. Guru dan orang tua bersama-sama mewujudkan lahirnya generasi baru yang berkualitas dan berkembang optimal.

\section{PENGHARGAAN}

Terima kasih yang berlimpah, tim PkM sampaikan kepada pengelola Yayasan Maria Bintang Samudera, pengelola PAUD Wejang Asih Mano, Kepala Sekolah PAUD Wejang Asih Mano, Para guru PAUD Wejang Asih Mano, serta para orang tua murid PAUD Wejang Asih Mano atas segala keterbukaannya dalam menerima tim PkM untuk melaksanakan kegiatan ini. Terima kasih untuk semua waktu, tenaga, dan materi yang telah diberikan selama kegiatan PkM ini berlangsung.

\section{REFERENSI}

[1] L. Marlisa, "Tuntutan Calistung pada Anak Usia Dini. Jurnal," J. Ilm. Tumbuh Kembang Anak Usia Dini., vol. 1, no. 3, pp. 25-38, 2016.

[2] L. Anhusadar, "Kreativitas Pendidik di Lembaga PAUD," Al-Ta'dib, vol. 9, no. 1, pp. 76-93, 2016.

[3] C. N. Irma, K. Nisa, and S. K. Sururiyah, "Keterlibatan Orang Tua dalam Pendidikan Anak Usia Dini di TK Masyithoh 1 Purworejo," J. Obs. J. Pendidik. Anak Usia Dini, vol. 3, no. 1, p. 214, 2019.

[4] K. Maryani, "Penilaian dan Pelaporan Perkembangan Anak Saat Pembelajaran di Rumah di Masa Pendemi Covid-19," Murhum J. Pendidik. Anak Usia Dini, vol. 1, no. 1, pp. 41-52, 2020.

[5] S. W. Prabhawani, "Pelibatan Orang Tua Dalam Program Sekolah DI TK Khalifah," J. Pendidik. Guru Pendidik. Anak Usia Dini, vol. 2, no. 5, pp. 205-218, 2016.

[6] T. Rihatno, Yufiarti, and N. Sri, "Pengembangan Model Kemitraan Sekolah Dan," no. 4, pp. 117-128, 2015.

[7] Biki Nur Lestari, "Pelaksanaan Program Parenting Kelompok Bermain (KB) Prima Sanggar Dalam Mendorong Keterlibatan Orang Tua Pada Pendidikan Anak," Pendidik. Luar Biasa, pp. 1-16, 2015.

[8] I. Arisanti, "Pendampingan Kemandirian Tpa Az-Zahra Berbasis Pemasaran Sosial," Din. J. Pengabdi. Kpd. Masy., vol. 3, no. 2, pp. 214-220, 2019.

[9] Z. Akbar, "Program Peningkatan Keterlibatan Orangtua Melalui Kegiatan Seni Pada Anak Usia Dini," Sarwahita, vol. 14, no. 01, pp. 53-60, 2017.

[10] M. Amini, "Profil Keterlibatan Orang Tua dalam pendidikan anak usia TK," J. Ilm. VISI PPTK PAUDNI, vol. 10, no. 1, pp. 9-20, 2015.

[11] U. Hasanah, "Analisis Praktik Pelibatan Orang Tua dan Masyarakat dalam Kegiatan Kreatif Anak Usia Dini : Studi Kasus di TK Pertiwi Ds.Tambah Rejo, Kec. Tunjungan Kab. Blora," Nadwa, vol. 11, no. 2, p. 177, 2017.

[12] E. Oktavianingsih, "Pengembangan Program Pelibatan Orangtua dalam Penyelenggaraan Pendidikan Anak Usia Dini," J. Early Child. Care Educ., vol. 1, no. 2, p. 1, 2019. 
[13] S. Setianingsih, "Dampak Penggunaan Gadget Pada Anak Usia Prasekolah Dapat Meningkatan Resiko Gangguan Pemusatan Perhatian Dan Hiperaktivitas," Gaster, vol. 16, no. 2, p. 191, 2018.

[14] A. Wardani and Y. Ayriza, "Analisis Kendala Orang Tua dalam Mendampingi Anak Belajar di Rumah Pada Masa Pandemi Covid-19," J. Obs. J. Pendidik. Anak Usia Dini, vol. 5, no. 1, p. 772, 2020.

[15] S. L. Iftitah and M. F. Anawaty, "Peran Orang Tua Dalam Mendampingi Anak Di Rumah Selama Pandemi Covid-19," JCE (Journal Child. Educ., vol. 4, no. 2, p. 71, 2020.

[16] N. Nurdin and L. Anhusadar, "Efektivitas Pembelajaran Online Pendidik PAUD di Tengah Pandemi Covid 19,” J. Obs. J. Pendidik. Anak Usia Dini, vol. 5, no. 1, p. 686, Aug. 2020.

[17] W. Yulianingsih, S. Suhanadji, R. Nugroho, and M. Mustakim, "Keterlibatan Orangtua dalam Pendampingan Belajar Anak selama Masa Pandemi Covid-19," J. Obs. J. Pendidik. Anak Usia Dini, vol. 5, no. 2, pp. 1138-1150, 2020. 